\title{
A Study of Professional Commitment among Secondary School Teachers in Relation to Self-Esteem, Gender and Length of Service
}

\author{
Mohd Hatim* and Mohd Shakir \\ Department of Education, Aligarh Muslim University, Aligarh, Uttar Pradesh, India \\ "Corresponding author: mohdhatimgd9845@gmail.com
}

Received: 09-01-2021

Revised: 28-02-2021

Accepted: $12-03-2021$

\begin{abstract}
This paper is related to the professional commitment among secondary school teachers. The purpose of present research was to study the relationship between professional commitment and self-esteem of secondary school teachers. Survey method is adopted for the present study. A sample of 136 secondary school teachers (63 Male \& 73 Female) was selected from the Aligarh District of Uttar Pradesh. Selfesteem questionnaire developed by Dr. Santosh Dhar and Dr. Upinder Dhar is used to assess the level of self-esteem. Professional commitment questionnaire developed by Ravinder Kaur, Sarbjit Kaur Ranu and Sarvjeet Kaur Brar is used to assess the level of professional commitment of teachers. Mean, SD, t-test \& correlation techniques are employed to analyze the data. Significant correlation was found between professional commitment and self-esteem of teachers. However, no significant difference was found in the professional commitment and self-esteem of male and female teachers. Also, there was no significant difference in the professional commitment and self-esteem of teachers having less than 10 years experience and teachers having more than 10 years experience. Therefore, it is better to enhance self-esteem of teachers to ensure higher level of professional commitment.
\end{abstract}

Keywords: Professional commitment, self-esteem, learning experience and secondary school teachers.

Educational institutions are known as temples of learning. These institutions provide a platform to perform important functions of providing learning experiences to the child. It is a place where mental abilities of the child are developed to make them able to think freely, clearly, and logically. Development of moral values, ethics, socially desirable behaviors and grooming of personalities of students also takes place in the educational institutions. It promotes innovation, peace, equality of opportunities, and adjustment in society. In India social problems like female foeticides, violence against women, rape, physical aggression, corruption, alcoholism, drug abuse, and superstitious beliefs etc. are still a big challenge. Educational institutions help individuals to think critically and understand these challenges and find possible solutions. Thus learning experience leads students from the ignorance to light of knowledge to live better and dignified life. The importance of educational institutions can be better understood by the statement given by Education Commission (1964-1966) that the destiny of India is now being shaped in her classrooms. The facilitators in the learning experiences who can play an important role in bringing significant transformation are the teachers. A teacher is a person who facilitates an educational programme, assesses participation of students, as well as administers or provides consistent and substantial

\footnotetext{
How to cite this article: Hatim, M. and Shakir, M. 2021. A Study of Professional Commitment among Secondary School Teachers in Relation To Self-Esteem, Gender and Length of Service. Educational Quest: An Int. J. Edu. Appl. Soc. Sci., 12(1): 29-35.
}

Source of Support: None; Conflict of Interest: None (क) 9 
guidance to an educational programme. Teachers are a most valuable resource to communities because teaching profession prepares all other professions. In any educational programme, teachers are central element. Implementation of any educational programme at any stage depends on the dedication, commitment and competency of teachers. In educational institutions the teachers and the students work together to develop worthwhile human resources for the welfare of mankind. As heart is necessary for human life, educational institutions are also important for human resource development. The learners who are the products of these educational institutions are expected to live in the society and take up responsibilities and ultimately provide services to the society.

\section{Professional Commitment}

Commitment is an indispensable component of all professions, not only in the teaching profession. Teaching profession is distinct in a number of ways. It involves a complex, rich and balance combination of working relation not only with the organization but with a number of other stakeholders, including the nation's philosophy, educational administrator, parents, students and colleagues. Commitment is part of a teacher's emotional intelligence. Teachers react according to their experience in a school setting. It is a part of a learned behaviour of a teacher. Teachers make conscious and subconscious decisions about their level of commitment on the basis of these affective reactions. According to Somech \& Bogler (2002) professional commitment possesses the characteristics "client orientation, loyalty, professional autonomy, conformity to professional standards and ethics".

\section{Self-Esteem}

In simple self-esteem means personal value or one's overall sense of self-worth. It is actually, how much we like ourself. It involves a variety of beliefs about ourself, it is about our appearance, beliefs, emotions, and behaviors. It is considered as one of the personality traits as it tends to be stable and enduring. It can play a significant role in our motivation and success throughout our life. Low self-esteem or our belief that we are not capable of success in anything may be a stumbling block in our way of achieving success on the other hand having a healthy self-esteem can help us in achieving our goals as here we go with positive, assertive attitude and we believe that we can accomplish our goals. Self-esteem is the acceptance of oneself as one's are at any given time in his/her life. Self-esteem means different things to different people. Self-Confidence is essential and anyone who wishes to build self-confidence starts with self-esteem. High selfesteem means that one feels good about one's self. High self-esteem is very crucial for experiencing love and success in life. When one's self-esteem is high, then has a sense of self-worth, one's value of oneself as a person. The term self-esteem is used in psychology to define a person's overall cognitive and affective aspect of his or her own worth. It is an evaluation of oneself as well as an attitude toward oneself. Self-esteem encompasses beliefs (for example, I am competent, I am worthy) and emotions such as triumph, I can, despair pride and shame. It is essential for educational achievement, health maintenance, financial success, and personal fulfillment, of everyday life. It is regarded as the antitoxin or remedy to underachievement, crime, and drug abuse.

\section{LITERATURE REVIEW}

A collective body of works done by previous researchers is technically called the literature. Any systematic investigation starts with a review of the relevant literature. It is an essential part of the research process which generates the ideas, helps in developing significant questions and act as an instrumental in the process of research design.

Professional Commitment: Professional commitment means dedication to develop themselves professionally, contributions to profession, feeling of loyalty, bonding and involvement to the profession. Shukla \& Waris (2016) studied professional commitment of secondary school teachers in relation to their gender and area. Result revealed that professional commitment of female secondary school teachers is better than their male counterparts. Basu (2016) revealed that male secondary school teachers possess significantly lower levels of professional commitment as compared to their female counterparts and less experienced teachers exhibit higher levels of professional commitment as compared to their more experienced counterparts. Pan (2016) found female 
teachers highly committed as compare to their male counterparts. Also found that teachers having less teaching experience are more committed than those of highly experienced teachers. Gill \& Kaur (2017) examined professional commitment among senior secondary school teachers. Result revealed that there is no significant difference in gender, location, and teaching experience between professional commitments among senior secondary school teachers. Bashir (2017) studied job satisfaction of teachers in relation to professional commitment. The result revealed that there is no significant difference between male and female secondary school teachers in their professional commitment. Habib (2019) studied the professional commitment of secondary school teachers. Result revealed that professional commitment is higher in female secondary school teachers than male secondary schoolteachers. Malik (2020) studied professional commitment among secondary school teachers in relations to personal stress in Covid-19 pandemic. The result revealed that professional commitment is influenced by the personal stress of a teacher.

Self-Esteem: Self-esteem is a judgment people make about themselves their abilities and attributes as well as their feeling of affection for oneself. For Instance Tabassum \& Ali (2012) studied the professional self-esteem of secondary school teachers. Result revealed that female teacher have higher level of professional self-esteem than male teacher. Shah \& Pathak (2014) studied on perceived self- esteem among secondary and higher secondary school teachers. Results of the study revealed that the gender and level of teaching experience do not play a significant role in the level of self-esteem of a person. Zafar, Mubashir, Tariq, Masood, Kazmi, Zaman \& Zahid (2014) revealed that self-esteem or overall job satisfaction is not affected by gender and type of school. Reilly, Dhingra, \& Boduszek (2014) studied on teachers' self-efficacy, beliefs, self-esteem, and job stress as determinants of job satisfaction. Results of the study revealed that no significant differences between male and female primary school teachers in regards to their job satisfaction, self-efficacy, self-esteem, and perceived stress. There is a weak negative relationship between teaching experience and job satisfaction. Stewart (2015) explored the potential relationship between the elementary school climate and teacher self-esteem which examine the role of teaching self-efficacy, perceived stress, self-esteem, and demographic characteristics in predicting job satisfaction. Result of the study reveals that no significant difference between male and female teachers on the basis of age, gender, education, and years of teaching experience. Moshahid (2017) studied the relationship between self-esteem and teaching skills of arts and science prospective teachers. Results of the study revealed that there is no significant difference in the self-esteem and teaching skills of male and female prospective teachers. Agir (2019) studied the effect of the perceived teacher behaviors on the self-esteem of students and their attitudes towards learning. The result revealed that the perceived teacher attitudes were weak and negatively related with self-esteem. Vivian, Quille, McGill, Falkner, Sentence, Barksdale, Busuttil, Cole, Liebe, \& Maiorana (2020) revealed that females teachers shows lower Computer Science self-esteem than males, those with no Computer Science teaching experience reported significantly lower Computer Science self-esteem than other teachers in groups.

Research Gap: There are many researches available to analyse the impact of self-esteem on others variables likes Zafar, Mubashir, Tariq, Masood, Kazmi, Zaman, \& Zahid (2014) on self-esteem and job satisfaction, Moshahid (2017) on the relationship between self-esteem and teaching skills, Benevene, Ittan, Cortini (2018) on self-esteem and happiness. But a very few amount of research is made on analysing the self-esteem on professional commitment of teachers. Therefore this study aims to analyse the psychological factor self-esteem and professional commitment of teachers to determine the professional commitment of secondary school teachers.

Significance of the Study: Self-esteem and professional commitment are of prime importance for a teacher. Both play a vital role in becoming a successful teacher. To improve the quality and competence of teachers it is necessary to ensuring proper professional commitment development of a teacher. Self-esteem is driving force which can accelerate the positive aspects in life and help in professional commitment. 


\section{OBJECTIVES OF THE STUDY}

1. To study the relationship between the mean scores of the professional commitment and the mean scores of the self- esteem of secondary school teachers.

2. To study the difference in the mean scores of the professional commitment of male and in the mean scores of female secondary school teachers.

3. To study the difference in the mean scores of the self-esteem of male and the mean scores of female secondary school teachers.

4. To study the collective effect of length of service on the mean scores of the professional commitment of secondary school teachers.

5. To study the collective effect of length of service on the mean scores of the self-esteem of secondary school teachers.

\section{HYPOTHESIS}

1. There is no significant relationship between the mean scores of the professional commitment and between the mean scores of the self-esteem of secondary school teachers.

2. There is no significant difference in between the mean scores of the professional commitment of male and between the mean scores of the female secondary school teachers.

3. There is no significant difference in between the mean scores of the self-esteem of male and between the mean scores of the female secondary school teachers.

4. There is no significant effect of length of service on the mean scores of the professional commitment of secondary school teachers.

5. There is no significant effect of length of service on the mean scores of the self-esteem of secondary school teachers.

Professional commitment: For present study professional commitment of a teacher is characterized by certain behavioral characteristics such as loyalty, professional autonomy, conformity to professional standards and ethics, excitement about teaching and learning, ability to innovate concerning mainly with the learner, society, profession, attaining excellence and basic human values.
Self-Esteem: For present study self-esteem is a term used to reflect a person's overall evaluation or appraisal of his or her own worth.

Sample: Survey method was used to study professional commitment among senior secondary school teachers. For the present study, 136 secondary school teachers who were teaching at $10^{\text {th }}$ grade from different schools of Aligarh Muslim University were selected randomly.

\section{Research tools used}

Professional Commitment Scale: The test standardized by Ravinder Kaur, Sarbjit Kaur Ranu, and Sarvjeet Kaur Brar (2011).

Self-Esteem Scale: The self-esteem scale developed and standardized by Dr. Santosh Dhar and Dr. Upinder Dhar (2015).

Administration of Test: Professional commitment score of the subject is the sum total of item scores of all the 05 areas. The theoretical range of scores is from 45 to 225 , high scores reflecting relatively higher level of professional commitment of teachers and vice-versa. Self-esteem score of the subject is the sum total of item scores of all six areas. The theoretical range of scores is from 23 to 115, high scores reflecting relatively higher level of self-esteem of teachers and vice-versa.

\section{Statistical Techniques}

Mean, SD, r and t-test, were applied for the analysis.

\section{ANALYSIS AND DISCUSSION}

Table 1: Correlation between professional commitment and self-esteem

\begin{tabular}{lcccccl}
\hline Basis & N & Mean & S.D & r & $\begin{array}{l}\text { Level of } \\
\text { significance }\end{array}$ \\
\hline $\begin{array}{l}\text { Professional } \\
\text { Commitment }\end{array}$ & 136 & 179.02 & 14.34 & 0.367 & 0.01 \\
\cline { 1 - 4 } Self-esteem & 136 & 98.84 & 7.02 & & \\
\hline
\end{tabular}

${ }^{*} 0.01$ level of significance.

It can be seen from the table 1 that the correlation between self-esteem and professional commitment among secondary school teachers is 0.367 . Though the correlation is not so strong, but it is positive and significant at 0.01 levels.

The table 2 shows that the mean score of professional 
Table 2: Gender wise professional commitment among secondary school teachers

\begin{tabular}{lllllll}
\hline Professional commitment & $\mathbf{N}$ & Mean & S.D & t- value calculated & t-value tabulated & Level of significance \\
\hline Male & 63 & 177.00 & 16.14 & \multirow{2}{*}{1.535} & 1.9778 & 0.05 \\
\hline Female & 73 & 180.76 & 12.45 & & \\
\hline
\end{tabular}

${ }^{*} 0.05$ level of significance.

Table 3: Gender wise self-esteem among secondary school teachers

\begin{tabular}{lllllll}
\hline Self Esteem & $\mathbf{N}$ & Mean & S.D & t- value calculated & t-value tabulated & Level of significance \\
\hline Male & 63 & 98.51 & 7.11 & .591 & \multirow{2}{*}{1.9778} & 0.05 \\
\hline Female & 73 & 99.22 & 6.95 & & \\
\hline
\end{tabular}

${ }^{*} 0.05$ level of significance.

Table 4: Professional commitment and length of service among secondary school teachers

\begin{tabular}{lcccccc}
\hline Professional commitment & N & Mean & S.D & $\begin{array}{l}\text { t- value } \\
\text { calculated }\end{array}$ & $\begin{array}{l}\text { t-value } \\
\text { tabulated }\end{array}$ & $\begin{array}{l}\text { Level of } \\
\text { significance }\end{array}$ \\
\hline $\begin{array}{l}\text { Teachers having less than } 10 \\
\text { years service }\end{array}$ & 68 & 180.80 & 14.47 & & & \\
\hline $\begin{array}{l}\text { Teachers having more than } 10 \\
\text { years of service }\end{array}$ & 68 & 177.23 & 14.09 & & 1.9778 & 0.05 \\
\hline
\end{tabular}

*0.05 level of significance.

commitment of male teachers is 177.00 while the mean score of professional commitment of female teachers is 180.76 . The computed $t$ value is 1.535 which is less than the table value at 0.05 levels. So, the null hypothesis is not rejected as there is no significant difference in the professional commitment of male and female teachers. This finding is supported by the study of Bashir (2017) in which researcher studied job satisfaction of teachers in relation to professional commitment. But the present findings is refuted in the study of Basu (2016) in which researcher conducted a study to investigate the professional commitment and job satisfaction of secondary school teachers.

The table 3 shows that the mean score of selfesteem of male teachers is 98.51 while the mean score of self-esteem of female teachers is 99.22 . The computed $t$ value is 0.591 which is less than the table value at 0.05 levels. So, the null hypothesis is accepted as there is no significant difference in the self-esteem of male and female teachers. This finding is supported by the study of Moshahid (2017) who conducted a study to find out the relationship between self-esteem and teaching skills of arts and science prospective teachers. But the present findings is refuted by the study of Tabassum
\& Ali (2012) they conducted on the professional self-esteem of secondary school teachers where female have higher level of professional self-esteem than male.

The table 4 shows that the mean score of teacher having less experience is 180.80 while the mean score teachers having more than 10 years experience is 177.23 . The computed $t$ value is 1.45 which is less than the table value at 0.05 levels. So, the null hypothesis is not rejected as there is no significant difference in the professional commitment of teacher having experienced less than 10 years and teachers having experienced more than 10 years. This findings is supported by the study of Gill \& Kaur (2017) in which they examined professional commitment among senior secondary school teachers in relation to gender, location, and teaching experience.

But the present study is refuted by the study of Pan (2016) who reported that teachers having less experience are more committed than those who are highly experienced teachers.

The table 5 shows that the mean score of teacher having less experience is 98.88 while the mean score teachers having more experience is 98.79 . The computed $t$ value is 0.073 which is less than the 
Table 5: Self-esteem among secondary school teachers

\begin{tabular}{lllllll}
\hline Demographic variable & $\mathbf{N}$ & Mean & S.D & t- value calculated & $\begin{array}{l}\text { t-value } \\
\text { tabulated }\end{array}$ & $\begin{array}{l}\text { Level of } \\
\text { significance }\end{array}$ \\
\hline Less than 10 years & 68 & 98.88 & 6.56 & 0.073 & 1.9778 & 0.05 \\
\hline More than 10 years & 68 & 98.79 & 7.50 & & \\
\hline
\end{tabular}

*0.05 level of significance.

table value at 0.05 levels. So, the null hypothesis is not rejected as there is no significant difference in the self-esteem of teachers having less than 10 years experience and teachers having more than 10 years experience. This finding is supported by the findings of Shah \& Pathak (2014).

\section{Findings of the Study}

There exist positive and moderate relationship between the professional commitment and the self- esteem of secondary school teachers.

$\square$ There is no significant difference in the professional commitment of the male and female secondary school teachers.

$\square$ There is no significant difference in the selfesteem of the male and female secondary school teachers.

There is no significant effect of length of service on the professional commitment of secondary school teachers.

$\square$ There is no significant effect of length of service on the self-esteem of secondary school teachers.

\section{CONCLUSION}

The major finding of the study showed that the professional commitment of secondary school teachers is positively correlated with self-esteem skills. It was found from the study that there is no significant difference in self-esteem and professional commitment between male and female teachers. It was also studied that whether there is any difference based on the length of service of teachers in selfesteem and professional commitment. The result showed that no significant difference was seen among teacher having experienced less than 10 years and teachers having experienced more than 10 years. The study also concluded that gender is not a key factor in deciding self-esteem and professional commitment of teachers. It is a symbol that female teachers are not inferior to male teachers in their educational practices. Teachers of both the gender are equally competent in professional commitment. It can be mentioned that high selfesteem is helpful in developing professional commitment. If, self-esteem domain of a teacher is not developed properly, it may adversely affect professional commitment of teachers. In the light of the above, it is suggested that administration of educational institutions should boost up the morale of teachers to develop high self-esteem and make proper arrangement to facilitate the teachers to develop their professional commitment which will ultimately helpful for enhancing the quality of school education.

Educational Implications: The administrator must take initiative to select those teachers who have high self-esteem. It is said that, a teacher with high self-esteem can well manage the self-esteem of his/her students. The self-esteem of teachers have profound influence on the development of children. Education for promoting self-esteem need to be recognized as an essential element of all training courses since this aspect strengthens the commitment and facilitates the attainment of goals. Educational institution during the admission test must frame questions from self-esteem for the admission in different teacher training programme. As teachers are important figure of an education system Government should make policies to reward and reinforce good teachers in order to increase their self-esteem and professional commitment to maintain standard of education. Administrators must take care of the personal problems of the teachers and see that they develop good and active inter-personal relations. The administrator can arrange necessary programme to focus on the training of self-esteem for the in-service teachers. Self-esteem programme can directly affect the level of professional commitment and well-being of person also. During In-service courses guidance and counselling session should be arranged regularly in order to enhance self-esteem, skills and motivate 
teachers which ultimately lead them towards professional commitment.

\section{REFERENCES}

Abdel-Khalek, A.M. 2016. Introduction to the Psychology of SelfEsteem. University of Alexandria, Egypt, Nova Science Publishers, Inc.

Agir, M.S. 2019. The Effect of Perceived Teacher Behaviors on Students' Self-Esteem and Attitudes towards Learning. J. Edu. Learn., 8(5): 203-218.

Attri, A.K. and Devi, N. 2017. Relationship between professional commitment and self-efficacy of secondary teacher educators. Int. J. Adv. Edu. and Res., 2(4): 42-44.

Bashir, L. 2017. Job Satisfaction of Teachers In Relation to Professional Commitment. Int. J. Indian Psycho., 4(4): 52-59.

Basu, S. 2016. Professional Commitment and Job Satisfaction among Secondary School Teachers. An Int. J. Edu. Appl. Soc. Sci., 7(3): 255-259.

Benevene, P., Ittan, M.M. and Cortini, M. 2018. Self-Esteem and Happiness as Predictors of School Teachers' Health: The Mediating Role of Job Satisfaction. Front. Psychol., https://doi.org/10.3389/fpsyg.2018.00933

Blascovich, J. and Tomaka, J. 1991. Measures of self-esteem. In: J.P. Robinson, P.R. Shaver, \& L.S. Wrightsman (Eds.) Measures of personality and social psychological attitudes, Volume I. San Diego, CA: Academic Press.

Branden, N. 2001. The Psychology of Self-Esteem: A Revolutionary Approach to Self-Understanding that Launched a New Era in Modern Psychology. New York, Jossey-Bass Inc.

Gill, P.K. and Kaur, H. 2017. A study of professional commitment among senior secondary school teachers. Int. J. Adv. Edu. and Res., 2(4): 253-257.

Gonda, M.G. 2014. Role of Educational Institutions in Shaping the Future of Business and Society. Procedia Eco. Fina., 11: $635-641$.

Habib, H. 2019. Professional Commitment of Secondary School Teachers in Relation to Their Self-Efficacy. Shanlax Int. J. Arts, Sci. and Humanities, 7(1): 35-38.

Hewitt, J.P. 2009. Oxford Handbook of Positive Psychology. Oxford University Press, pp. 217-224.

India. 1966. Report of the Education Commission, 1964-66: Education E national development. New Delhi: Ministry of Education, Govt. of India.

Kaur, S.J., Sharma, Y. and Mathur, A. 2015. New Trend in Education. New Delhi: Renu Publishers, pp. 124-125.

Kumar, R. and Varma, B. 2018. Academic Interest and Self Esteem: A Study on Gender Differences among Adolescents. Int. J. Res. Analy. Rev., 5(3): 60-63.

Malik, M. 2020. Professional Commitment among Secondary School Teachers of Gurugram District in Relation to Personal Stress in Covid-Pandemic. Mukt Shabd J., 9(6): 5553-5558.

Malm, B. 2009. Towards a new professionalism: enhancing personal and professional development in teacher education. Int. Res. Pedagogy, 35(1): 77-91.

Moore, J. 1997. Teachers and self-esteem. An Int. J. Humanistic Psychology, 25(5): 15-17.

Moshahid, M. 2017. A study of self-esteem and teaching skills among arts and science prospective teachers. Int. J. Adv. Edu. Res., 2(3): 99-102.

Neetu, A. 2015. Changing Context of Teacher Education Indian Scenario. Aca. Disco., 4(1): 63-71.

Pan, A. 2016. Professional Commitment of Teacher Educators of Self-Financed B. Ed. Colleges of West Bengal. The Scholar, 1(2): 20-28.

Rani, A. 2017. Problems and Solution of Teacher Education. Int. J. Academic Res. Edu. Rev., 5(1): 15-19.

Reilly, E., Dhingra, K. and Boduszek, D. 2014. Teachers' self-efficacy beliefs, self-esteem, and job stress as determinants of job satisfaction. Int. J. Edu. Mgt., 2(4): 365-378.

Shah, K. and Pathak, S. 2014. Perceived Self- Esteem among Secondary and Higher Secondary School Teachers. Int. J. Indian Psychology, 2(1): 28-34.

Singh, A.K. 2017. Test, Measurement and Research Methods in Behavioural Sciences. New Delhi, Bharati Bhawan.

Singh, S.K. 2016. Roles of Teachers in Global Scenario in $21^{\text {st }}$ Century. Lunawada, Redshine International Press, pp. 27-28.

Shrivastava, S.K. 2016. Role of Educational Institutions in Promoting Social Awareness. Int. J. Inno. Res. Adv. Stu., 3(13): 24-26.

Shukla, A.K. and Waris, A. 2016. Professional Commitment of Secondary School Teachers in Relation to Their Gender and Area: A Comparative Study. Global J. Res. Analy., 5(7): 264-265.

Stewart, K.D. 2015. The Elementary School Climate and Teacher Self-esteem: A Study of Potential Relationship. Master of Soc. Work Cli. Res., 5(1): 1-64.

Tabassum, F. and Ali, M. 2012. Professional Self-esteem of Secondary School Teachers. Asian Soc. Sci., 8(2): 206-210.

Varma, B. and Kumar, R. 2018. Academic interest and selfesteem: a study on gender differences among adolescents. Int. J. Res. Analy. Rev., 5(3): 60-63.

Vivian, R., Quille, K., McGill, M.M., Falkner, F., Sentence, S., Barksdale, S., Busuttil, L., Cole, E., Liebe, C. and Maiorana, F. 2020. An International Pilot Study of K-12 Teacher's Computer Science Self-Esteem. ACM Conference on Innovation and Technology in Computer Science Education, Trondheim, Norway, pp. 117-123.

Zafar, N., Mubashir, T., Tariq, S., Masood S., Kazmi, F., Zaman, H. and Zahid, A. 2014. Self-esteem and Job Satisfaction in Male and Female Teachers in Public and Private Schools. Pak. J. Soc. and Clinical Psychology, 12(1): 46-50.

https://www.verywellmind.com/what-is-self-esteem 2795868\#: : text=In \%20psychology $\% 2$ C $\% 20$ the $\% 20$ term $\% 20$ self,beliefs $\% 2$ C $\% 20$ emotions $\% 2 C \% 20$ and $\% 20$ behaviors. 
